\title{
Effect of Jigsaw Cooperative Learning Strategy in Promoting Insightful Learning of Junior Intermediate Students in Mathematics
}

\author{
Chinna Suresh $^{1 *}$, Prof. V. Dayakara Reddy ${ }^{2}$
}

\section{ABSTRACT}

The teachers constantly face the problem of finding appropriate teaching methods and applying the most effective method of instruction that could enrich the teaching-learning process and cater the student diversity in the most heterogeneous classroom. Hence in this context, the investigators made an attempt to study the effect of Jigsaw Cooperative learning technique in enhancing the Scholastic achievement in Mathematics of Junior Intermediate students $(+1$ students). The objectives of the study is 1) To assess the effectiveness of Jigsaw cooperative learning strategy in enhancing scholastic achievement in mathematics of junior intermediate students. 2) To find out the significant difference if any in the scholastic achievement in mathematics of junior intermediate students due to different teaching methods. A sample of 120 students was included in the study. The pre-test post-test equivalent method was used for the present study. The experimental design used for the Present study was Quasi-experimental design. The Raven's Standard progress matrices test and investigator self-designed scholastic achievement test was used to collecting the data. The analysis was done by Central tendency measures and t-test. Findings revealed that 1) the group of students assigned for Jigsaw Cooperative learning technique is achieved significantly higher mean score in scholastic achievement test than that of the Conventional method of teaching in terms of Total Sample; The performance of Male and female Students in Cooperative learning group is achieved significantly higher mean scores in scholastic Achievement test than that of the male and female students assigned to Conventional method of teaching; The Above average, Average and Below Average group students who thought through Jigsaw Cooperative learning technique is achieved significantly higher mean scores in scholastic Achievement test than that of Conventional method of teaching; And also significant gender differences were not established in scholastic achievement of students.

Keywords: Cooperative learning, Jigsaw Strategy, Scholastic achievement, Achievement levels.

\footnotetext{
${ }^{1}$ Research Scholar, Department of Education, Sri Venkateswara University, Tirupati, India

${ }^{2}$ Research Supervisor, Department of Education, Sri Venkateswara University, Tirupati, India

*Responding Author
}

Received: December 30, 2016; Revision Received: January 20, 2017; Accepted: January 30, 2017

(C) 2017 Chinna S, Reddy D; licensee IJIP. This is an Open Access Research distributed under the terms of the Creative Commons Attribution License (www.creativecommons.org/licenses/by/2.0), which permits unrestricted use, distribution, and reproduction in any Medium, provided the original work is properly cited. 


\section{Effect of Jigsaw Cooperative Learning Strategy in Promoting Insightful Learning of Junior Intermediate Students in Mathematics}

For any educational system teaching is a key factor where a transfer of knowledge takes place from a teacher to learner. The aim of the education is to train the child how to learn the new things. At present if you consider in higher secondary (Junior Intermediate) classrooms in Indian education system where a majority of the teachers are following Lecture Method that is a 'teacher-centered' method in their instruction. Reasons behind for adopting teacher-centered methods is 1) not willing in adopting innovative instructional strategies. 2) Lack of sufficient human resources and infrastructural facilities 3) Teachers wants to complete the prescribed syllabus well in advance before the prescribed time limit and prepare the students to produce good marks and good grades in the final examination for the fulfillment of degree by defeating the very purpose of education. According to Louis Rath (1997) "the good teaching is explaining, informing, initiating, directing, administering, unifying the group, giving security, clarifying, diagnosing, learning problems, preparing curriculum material, evaluating, recording, reporting, enriching community activities, organising and arranging classrooms, participating in school activities and in professional development". In this teacher-centred learning process, the students used to adopt route learning and reproducing the same content material what they memorized in their examinations for better marks and better grades. The individual difference in a heterogeneous classroom is completely ignored. No measures are taken to cater the different needs of the pupils. To avoid this, several attempts have been made to systematize ways of

meeting individual differences among the pupils in the classroom and to make teaching-learning more effective and fruitful. Especially the constructivist's contribution in this field is worth notable. They developed a new dimension of learning where learning considered as a constructivists process in which learners do not passively receive information but instead actively construct knowledge as they strive to make sense of their worlds. Constructivism thus gave a new definition for the concept of teaching-learning and brought revolutionary changes in the field of Education. This is supported by research studies all over the world.

The Constructivists proposed several instructional strategies among the Cooperative learning, Collaborative learning, Problem-based learning etc., are prominent. Therefore, to keep pace with changing circumstances, we should not keep away ourselves from new experiments in the field of education to make learning more effective and enjoyable experiences for pupils. This fact inspired the investigators to undertake the present study.

\section{What is Cooperative Learning?}

Cooperative learning is a Student-Centered, instructor-facilitated instructional strategy in which a small group of students is responsible for its own learning and the learning of all group members. Students interact with each other in the same group to acquire and practice the elements of subject matter in order to solve a problem, complete a task of achieving a goal. 
According to Kagan (1989) in Cooperative learning the teacher designs the social interaction structures as well as learning activities. Johnson, Johnson, and Holubec (1993) state that in Cooperative learning students can maximize their own and each other's learning whey they work together. Slavin (1996) argues that a Critical element of an element of Cooperative learning is group teamwork and team goals.

Johnson and Johnson and Holubec (1991) proposed five key elements of Cooperative learning are Positive Interdependence, Individual accountability, Promotive Interaction, Interpersonal and small-group skills, and Group Processing.

\section{Jigsaw model of Cooperative Learning:}

In this model of Cooperative learning technique the whole class can be divided into small groups consisting of 4 to 6 members in each group with diverse in terms of gender, race, ethnicity and ability and these groups are called as a Base Groups. The lesson to be taught can be divided into 4 or 6 segments and each student is assigned to learn one segment. Once the students become familiar with their assigned segments, each student meet with the students of the other groups who have the same assigned segments and form an expert group. This expert group learns the material together, share information they have learned. After an appropriate amount of time, the students regroup with the original groups; one by one they teach others what they have learned. The teacher observes each group and acts as a facilitator, helping poor, quieter students and intervening when students are too talkative and monopolizing.

\section{Objectives of the study:}

The present study was undertaken with the following objectives:

1. To Study the effectiveness of Cooperative Learning Strategy (Jigsaw) in enhancing Scholastic Achievement of Junior Intermediate student in terms of the total sample.

2. To investigate the effectiveness of Cooperative Learning Strategy (jigsaw) in enhancing Scholastic Achievement of Junior Intermediate students with respect to Gender, and Achievement levels.

\section{Hypotheses of the Study:}

To Study the present problem researchers formulated the following hypotheses:

1. Cooperative Learning as a Strategy is no effective than the Conventional method of teaching with reference to Scholastic Achievement of Junior intermediate Students in the total sample.

2. There will be no Significant difference between the Post-test mean scores of Jigsaw Cooperative learning group and the Conventional method group with respect to scholastic Achievement of Junior intermediate Students with respect to a) Gender, and b) Achievement levels. 


\section{METHODOLOGY}

The Study was experimental in nature. The quasi-Experimental design with equivalent pre-test and post-test design was followed. Purposive Sampling technique was followed to include the sample in the study. The study consists of 120 junior intermediate students with mathematics as one of group subject from two different Govt. Junior colleges, in Kurnool district of Andhra Pradesh (i.e. 60 students from each college). Raven's Standard Progressive Test was administrated to establish the homogeneity between the experimental and control groups. To measures the scholastic achievement in Mathematics, investigator designed scholastic achievement test in Mathematics on topic "Straight Lines" was administrated. The pre-test was administrating for both the groups before the treatment. For Experimental (Jigsaw) and Control (Conventional) groups the topic 'Straight Lines' was taught for a period of one month. After the treatment period, post-test was administrated to both the groups to measure the effect of Jigsaw Cooperative technique.

\section{Sample:}

The population of the present research is junior intermediate students. In the present study, the investigators by employing purposive sampling technique selected 120 junior intermediate students who are studying in two different Govt. Intermediate colleges located in Kurnool district of Andhra Pradesh.

\section{Tools:}

The following tools are used to collect the data

1. In this investigation, the investigators adopted Raven's Progressive Matrices scale developed by Raven's to establish the homogeneity between the groups.

2. Investigators self-designed scholastic achievement test in mathematics were administrated to measure the scholastic achievement in mathematics. It consists of 50 items in it. This tool has constructive, content, face validity and reliability.

\section{Analysis of Data:}

Data was analyzed by using Mean, SD and t-test.

\section{RESULTS AND DISCUSSIONS}

The obtained results from the analysis were presented and discussed in two parts

\section{Before the Treatment:}

Ho-1: There is no significant difference between Pre-test Scores of Experiment and Control group with reference to their Scholastic Achievement in Mathematics in terms of a) Total Sample, b) Gender and c) Achievement level 
Effect of Jigsaw Cooperative Learning Strategy in Promoting Insightful Learning of Junior Intermediate Students in Mathematics

Table: 1, N, Mean, S.D, 't' value of Scholastic achievement of experimental and control group before treatment (Pre-test)

\begin{tabular}{|c|c|c|c|c|c|c|c|c|c|}
\hline \multicolumn{2}{|c|}{ Variable } & Group & $\mathbf{N}$ & Df & Mean & S.D & p-value & t-valve & Sign. \\
\hline \multirow{2}{*}{\multicolumn{2}{|c|}{ Total Sample }} & Exp. & 60 & \multirow{2}{*}{118} & 25.10 & 6.766 & \multirow{2}{*}{0.33} & \multirow{2}{*}{0.96} & \multirow{2}{*}{ NS* } \\
\hline & & Cont & 60 & & 23.80 & 8.01 & & & \\
\hline \multirow{2}{*}{\multicolumn{2}{|c|}{ Gender- Male }} & Exp & 33 & \multirow{2}{*}{64} & 23.18 & 5.80 & \multirow{2}{*}{0.52} & \multirow{2}{*}{0.63} & \multirow{2}{*}{ NS* } \\
\hline & & Cont. & 33 & & 22.66 & 8.65 & & & \\
\hline \multirow{2}{*}{\multicolumn{2}{|c|}{ Gender - Female }} & Exp. & 27 & \multirow[b]{2}{*}{52} & 26.66 & 7.60 & \multirow{2}{*}{0.45} & \multirow{2}{*}{0.74} & \multirow[b]{2}{*}{ NS* } \\
\hline & & Cont. & 27 & & 25.18 & 7.00 & & & \\
\hline \multirow{6}{*}{$\begin{array}{l}\text { Achievement } \\
\text { Levels }\end{array}$} & \multirow{2}{*}{$\begin{array}{l}\text { Above } \\
\text { Average }\end{array}$} & Exp & 11 & \multirow[b]{2}{*}{20} & 32.00 & 2.60 & \multirow{2}{*}{0.51} & \multirow{2}{*}{0.65} & \multirow{2}{*}{ NS* } \\
\hline & & Cont & 11 & & 33.18 & 5.36 & & & \\
\hline & \multirow{2}{*}{ Average } & Exp & 34 & \multirow{2}{*}{66} & 24.64 & 6.559 & \multirow[t]{2}{*}{0.42} & \multirow{2}{*}{0.80} & \multirow{2}{*}{ NS* } \\
\hline & & Cont. & 34 & & 23.35 & 6.678 & & & \\
\hline & \multirow{2}{*}{$\begin{array}{l}\text { Below } \\
\text { Average }\end{array}$} & Exp & 15 & \multirow{2}{*}{28} & 21.06 & 5.599 & \multirow[t]{2}{*}{0.15} & \multirow{2}{*}{1.45} & \multirow{2}{*}{$\mathrm{NS}^{*}$} \\
\hline & & Cont. & 15 & & 17.93 & 6.192 & & & \\
\hline
\end{tabular}

NS: Not Significant at 0.05 level.

It is observed From the Table-1, the computed t-value for Total Sample (0.96) is less than the critical t-value 1.98 at df 118 and not significant at 0.05 level of significance; the computed tvalue for Gender-Male (0.63) is less than the t-critical value 1.98 at $\mathrm{df} 64$ and not significant at 0.05 level of significance; the computed t-valve for Gender-Female (0.74) is less than the critical t-value 2.00 with df 52 and not significant at 0.05 level of significance; the computed tvalue (0.65) for Above Average students is less than the critical t-value 2.08 at df 20 and not significant at 0.05 level of significance; the computed t-value (0.80) for Average level student is less than the t-critical value 1.98 at df 66 and not significant at 0.05 level of significance; the computed t-valve (1.45) for Below average Students is less than the critical t-value (2.04) and not significant at 0.05 level of significance. Therefore the null hypotheses that the Experimental group does not differ with the Control group with reference to Scholastic Achievement in Mathematics in terms of Gender, Achievement levels is accepted. Hence, it is concluded that the Experimental and Control groups were alike with reference to Scholastic achievement in Mathematics before the treatment. That means, the entry behaviour of all the Junior Intermediate students irrespective of Experimental and Control groups with reference to a dependent variable (i.e. Scholastic Achievement in Mathematics) were same and the groups are almost homogeneous with reference to the selected variable. It also confirms the appropriateness of matching of the groups. Therefore, it may be concluded that the difference noticed in enhanced Scholastic Achievement in Mathematics after the application of treatments may be attributed to the treatment only. 
Effect of Jigsaw Cooperative Learning Strategy in Promoting Insightful Learning of Junior Intermediate Students in Mathematics

\section{After the treatment}

Ho-2: There is no significant difference between the post-test mean scores of Experimental and Control groups with reference to Scholastic Achievement in Mathematics in terms of a) gender and b) Achievement levels.

Table: 2, N, Mean, S.D, 't' value of Scholastic Achievement in Mathematics of experimental and control group After treatment (Post-test)

\begin{tabular}{|c|c|c|c|c|c|c|c|c|c|}
\hline \multicolumn{2}{|c|}{ Variable } & Group & $\mathbf{N}$ & Df & Mean & S.D & p-value & t-valve & Sign. \\
\hline \multirow{2}{*}{\multicolumn{2}{|c|}{ Total Sample }} & Exp. & 60 & \multirow{2}{*}{118} & 32.80 & 5.698 & \multirow{2}{*}{0.00} & \multirow{2}{*}{6.49} & \multirow{2}{*}{$0.01 * *$} \\
\hline & & Cont. & 60 & & 24.83 & 8.012 & & & \\
\hline \multirow{2}{*}{\multicolumn{2}{|c|}{ Gender- Male }} & Exp. & 33 & \multirow[b]{2}{*}{64} & 32.15 & 5.220 & \multirow[b]{2}{*}{0.00} & \multirow{2}{*}{5.34} & \multirow{2}{*}{$0.01 * *$} \\
\hline & & Cont. & 33 & & 23.39 & 7.822 & & & \\
\hline \multirow{2}{*}{\multicolumn{2}{|c|}{ Gender - Female }} & Exp. & 27 & \multirow{2}{*}{52} & 33.59 & 6.240 & \multirow{2}{*}{0.00} & \multirow{2}{*}{3.84} & \multirow{2}{*}{$0.01 * *$} \\
\hline & & Cont. & 27 & & 26.59 & 7.094 & & & \\
\hline \multirow{6}{*}{$\begin{array}{l}\text { Achievement } \\
\text { Levels }\end{array}$} & \multirow{2}{*}{\begin{tabular}{|l} 
Above \\
Average
\end{tabular}} & Exp & 11 & & 37.72 & 3.495 & \multirow{2}{*}{0.00} & \multirow{2}{*}{3.92} & \\
\hline & & Cont & 11 & & 34.90 & 4.908 & & & \\
\hline & \multirow{2}{*}{ Average } & Exp & 34 & \multirow{2}{*}{66} & 32.20 & 4.304 & \multirow{2}{*}{0.00} & \multirow{2}{*}{6.63} & \multirow{2}{*}{$0.01 * *$} \\
\hline & & Cont. & 34 & & 24.14 & 5.62 & & & \\
\hline & \multirow{2}{*}{$\begin{array}{c}\text { Below } \\
\text { Average }\end{array}$} & Exp & 15 & \multirow[t]{2}{*}{28} & 28.13 & 3.796 & \multirow[t]{2}{*}{0.00} & \multirow{2}{*}{5.03} & \multirow{2}{*}{$0.01 * *$} \\
\hline & & Cont. & 15 & & 19.00 & 5.916 & & & \\
\hline
\end{tabular}

Note: ** significant at $1 \%$ level.

From the Table-2, it observed the computed t-value for Total Sample (6.49) is greater than the critical t-value 2.61 at df 118 and not significant at 0.01 level of significance; the computed tvalue for Gender-Male (5.34) is greater than the critical t-value 2.61 at df 64 and not significant at 0.01 level of significance; computed t-value for Gender-Female(3.84) is Greater than the tcritical value 2.39 at df 52 and not significant at 0.01 level of significance; computed t-value for Above Average Students (3.92) is greater than the t-critical value 2.84 at df 20 and not significant at 0.01 level of significance; computed t-value for Average Students (6.63) is greater than the t-critical value 2.6 at $\mathrm{df}$ and not significant at 0.01 level of significance; computed t-value for (5.03) for Below average students is greater than the critical t-value 2.46 at df 28 and not significant at 0.01 level of significance. Therefore the null hypotheses that there is no significant difference between the post-test scores of Experimental and Control groups with reference to Dependent variable in terms of gender, Achievement levels is rejected and an alternative hypothesis accepted. This shows that there exists a significant difference between the post-test scores in Experimental and Control group with respect to a dependent variable after treatment and these is due to the treatment.

\section{FINDINGS}

1. Significant variation exists in the scholastic achievement of junior intermediate students between Experimental and Control groups in total after the treatment.

(c) The International Journal of Indian Psychology, ISSN 2348-5396 (e)| ISSN: 2349-3429 (p) | 74 
Effect of Jigsaw Cooperative Learning Strategy in Promoting Insightful Learning of Junior Intermediate Students in Mathematics

2. There is a significant difference in the scholastic achievement of junior intermediate students with regards to gender and Achievement levels after the treatments.

3. No significant gender difference was established in scholastic achievement of students after the treatment.

\section{CONCLUSION}

The school is a miniature of Society which consists students of different ages, religions, languages, intelligence levels and so on. In this context teaching is a very crucial point. The existing student-teaching programme needs to incorporate the principles of Cooperative learning. The Study found out that, Cooperative learning helps the students in enhancing of their achievement as such. The study found to be more effective irrespective of the subject discipline. Therefore all the teachers should invariable organize group discussions and group seminars, Project-activities etc. In such collective works, students will develop an ability to work in groups.

\section{Acknowledgments}

The author appreciates all those who participated in the study and helped to facilitate the research process.

\section{Conflict of Interests}

The author declared no conflict of interests.

\section{REFERENCES}

Aggarwal. Y.P (1978), "Statistical Methods", New Delhi: Sterling publication Pvt. Ltd.

Ayhan Dikici, Yasemin Yavuzer (2006) " The effects of Cooperative Learning on the abilities of Pre-service art teacher candidates to lesson Planning in turkey", Australian journal of teacher education, 31,2 .

P.K. Sudheesh Kumar and Bindu (2001) "Instructional learning strategies and cognitive entry behaviour"-An Experimental Analysis, Kanishka Publishers, and distributors, New Delhi.

P.K.Sudheesh Kumar and P.Sasidharan-"Jigsaw Process in Education"- The way for Joyful learning.

Santhosh Sharma (2006)- Constructivists Approaches to Teaching and Learning-A Hand Book for teachers in Secondary Stage', Published by NCERT, New Delhi.

How to cite this article: Chinna S, Reddy D (2017), Effect of Jigsaw Cooperative Learning Strategy in Promoting Insightful Learning of Junior Intermediate Students in Mathematics, International Journal of Indian Psychology, Volume 4, Issue 2, No. 86, ISSN:2348-5396 (e), ISSN:2349-3429 (p), DIP:18.01.030/20170402, ISBN:978-1-365-68609-2 